\title{
From \\ HEAVEN TO EARTH
}

姃 



\title{
From \\ HEAVEN TO EARTH

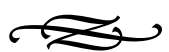

\author{
THE REORDERING OF \\ CASTILIAN SOCIETY, $1150-1350$
}

Teofilo F. Ruiz

PRINCETON UNIVERSITY PRESS

PRINCETON AND OXFORD 
COPYRIGHT @ 2004 BY PRINCETON UNIVERSITY PRESS

PUBLISHED BY PRINCETON UNIVERSITY PRESS, 41 WILLIAM STREET,

PRINCETON, NEW JERSEY 08540

IN THE UNITED KINGDOM: PRINCETON UNIVERSITY PRESS, 3 MARKET PLACE, WOODSTOCK, OXFORDSHIRE OX20 ISY

ALL RIGHTS RESERVED

\section{LIBRARY OF CONGRESS CATALOGING-IN-PUBLICATION DATA}

RUIZ, TEOFILO F., 1943-

FROM HEAVEN TO EARTH : THE REORDERING OF CASTILIAN SOCIETY, 1150-1350 /

TEOFILO F. RUIZ.

P. CM.

INCLUDES BIBLIOGRAPHICAL REFERENCES AND INDEX.

ISBN 0-691-00121-9 (CL : ACID-FREE PAPER)

1. CASTILE (SPAIN) -SOCIAL CONDITIONS. 2. CASTILE (SPAIN)-HISTORY. 3. LAND

TENURE-SPAIN-CASTILE-HISTORY. I. TITLE.

$$
\begin{array}{cl}
\text { HN590.C36R837 } & 2004 \\
306^{\prime} .0946^{\prime} 3-D C 21 & 2003045979
\end{array}
$$

BRITISH LIBRARY CATALOGING-IN-PUBLICATION DATA IS AVAILABLE

THIS BOOK HAS BEEN COMPOSED IN GALLIARD

PRINTED ON ACID-FREE PAPER. $\infty$

WWW.PUPRESS.PRINCETON.EDU

PRINTED IN THE UNITED STATES OF AMERICA

$\begin{array}{llllllllll}1 & 3 & 5 & 7 & 9 & 10 & 8 & 6 & 4 & 2\end{array}$ 
To Jacques Le Goff

MAÎTRE ET AMI

$\approx$ 
